\title{
Technostress in Spanish University Students: Validation of a Measurement Scale
}

\author{
María Penado Abilleira ${ }^{*}$, María Luisa Rodicio-García ${ }^{2}$, María Paula Ríos-de-Deus² and \\ María José Mosquera-González²
}

${ }^{1}$ Facultad de Ciencias de la Salud, Universidad Isabel I, Burgos, Spain, ${ }^{2}$ Unidad de Investigación FORVI (Formación y Orientación para la Vida), Universidad de A Coruña, A Coruña, Spain

OPEN ACCESS

Edited by: África Borges,

University of La Laguna, Spain

Reviewed by:

Leire Aperribai,

University of the Basque Country,

Spain

FCo. Pablo Holgado-Tello, National University of Distance

Education (UNED), Spain

*Correspondence: María Penado Abilleira maria.penado@ui1.es; mariapenado@gmail.com

Specialty section:

This article was submitted to

Quantitative Psychology

and Measurement,

a section of the journal

Frontiers in Psychology

Received: 11 July 2020 Accepted: 07 September 2020

Published: 29 October 2020

Citation:

Penado Abilleira $M$

Rodicio-García ML, Ríos-de-Deus MP and Mosquera-González MJ (2020) Technostress in Spanish University

Students: Validation of a

Measurement Scale

Front. Psychol. 11:582317. doi: 10.3389/fpsyg.2020.582317
The increasingly widespread use of technology has led to the emergence of phenomena harmful to users such as technostress. Although technostress has already been studied in other contexts, it is still pending study in a university education environment, where the use of information and communication technologies is increasingly widespread. Thus, the objective of this study was to adapt a technostress questionnaire for Spanish university students based on an instrument that had been designed in a Chinese university teaching population. A total of 1,744 Spanish university students from faceto-face and online universities completed the adapted Spanish technostress scale. Factorial analyses suggested the elimination of two items from the original scale and a model made up of five factors that fit, as in the original scale, within the personenvironment misfit theory. The reduced scale also showed good internal consistency for all the items and the five resulting factors. These results support the psychometric properties of the reduced technostress scale in university students, and their validity when offering a complete view of the phenomenon in Spain.

Keywords: technostress, university, students, questionnaire, Spanish validation

\section{INTRODUCTION}

Technostress is as an adaptive disease caused by the lack of ability to deal with new computer technologies in a healthy way. Its conception and etymology can be traced to the 1980s with the publication of the book Technostress: The Human Cost of the Computer Revolution (Brod, 1984), which mainly pointed out the negative aspects of computer use. In a little over a decade, this understanding of technostress was nuanced by Weil and Rosen $(1997$, p. 5) to include "the negative impacts on attitudes, thoughts or behaviors, caused directly or indirectly through technology," thus allowing a sufficiently broad definition of the phenomenon to incorporate successive technological advances.

In the Spanish sphere, Salanova (2003) considers technostress as:

\footnotetext{
A negative psychological state related to the use of ICT or a threat to its use in the future. This state is conditioned by the perception of a mismatch between demands and resources related to the use of ICTs leading to a high level of unpleasant psychophysiological activation and the development of negative attitudes towards ICT (p. 231).
} 
From this definition, various theoretical models that try to specifically explain the emergence of stress related to the use of technology within organizations have been proposed, which are either based on general classical theories of stress or specifically arise to explain this phenomenon.

A transactional model of stress and coping defines psychological stress as "a particular relationship between the person and the environment that is considered as an imposition or an overcoming of their resources and endangers their wellbeing" (Lazarus, 1966; Lazarus and Folkman, 1984). Thus, technostress occurs when the competency requirements of information and communication technology (ICT) exceed the level of real user competence within an organization, or when technological demands exceed the resources or capacity to face them (Tarafdar et al., 2010, 2015; Ayyagari et al., 2011; Hung et al., 2011; Fuglseth and Sørebø, 2014; Yin et al., 2014; Galluch et al., 2015; Srivastava et al., 2015; Fischer and Riedl, 2017).

According to the job demands-resources model (Demerouti et al., 2001), each work environment has its own characteristics that can be divided into two general categories (i.e., work demands and work resources). Moreover, this model states that the health and wellbeing of employees are the result of a balance between positive (i.e., resources) and negative (i.e., demands) work characteristics. Applying this to the phenomenon at hand (Salanova et al., 2007; López-Araujo and Osca, 2008; Wang et al., 2020), the supporters of this theory explain that technostress results from high demands (i.e., techno demands) and lack of technological resources (i.e., techno resources) at work.

In addition, the person-environment misfit theory (P-E fit theory; Harrison, 1978; Edwards, 1996; Edwards et al., 1998) assumes that there is an equilibrium between people and their environment; when this relationship is out of balance, tension is generated (Ayyagari et al., 2011). Stress is caused neither by the person nor the environment, but appears when there is no adjustment between the two (e.g., between the needs of the person and the resources of the environment, or between the aptitudes and abilities of the person and the demands of the environment). Thus, technostress is conceptualized as a misfit between a person and the environment. It is not only limited by technology itself but also by the organization that has established the requirements for its use, and the members of the organization that on multiple occasions have an influence on the individual's use of technology (Avanzi et al., 2018).

Most measurement instruments have focused on the subjective experience of technostress, dimensioning it in five different factors known as techno-invasion, techno-insecurity, techno-complexity, techno-uncertainty, and techno-overload (Tarafdar et al., 2007; Ragu-Nathan et al., 2008; Wang et al., 2008; Salanova et al., 2013; Chen, 2015; Alam, 2016; Chen and Muthitacharoen, 2016; Krishnan, 2017; Chandra et al., 2019). In this way, the objective perspective of the person-environment interaction, or the elements described in the previous theories, are being ignored. Thus, technostress is conceptualized as an imbalance between the technological skills of the subjects and the technological demands of the institution in which they work.

Despite the breadth of studies that focus on the negative consequences of technostress (Tarafdar et al., 2015; Hsiao, 2017) and its influence on work performance (Jung et al., 2012; Jena, 2015), practically all of these studies focus on administration and industry (Ragu-Nathan et al., 2008; Fuglseth and Sørebø, 2014; Marchiori et al., 2019). In general, these works ignored the rapid technological advances that have been incorporated in the field of education, and university education in particular, and has allowed today the use of new technologies for teaching online.

In the university context, Wang and Li (2019) have been the only authors that have corroborated the P-E fit theory as an explanatory model of technostress in a sample of university professors from five Chinese universities. This validated a measurement instrument specifically adapted for higher education and showed how dimensions of the aforementioned theory can affect the work performance of teachers.

Based on previous studies, the objective of this research is twofold:

1. To determine whether the theoretical perspective of the P-E fit theory explains the existence of technostress among Spanish university students.

2. To adapt the teacher technostress questionnaire by Wang and Li (2019) for Western university students and corroborate its psychometric properties.

\section{MATERIALS AND METHODS}

\section{Procedure and Participants}

The adaptation of the Wang and Li (2019) technostress questionnaire for Spanish students began with a translation of the elements that make up the original scale into Spanish by specialized translators from the Official School of Languages at the University of A Coruña. After, the items were adapted for a university students population. In this process, references to teaching were replaced with academic tasks or studies (e.g., study and school work), while references to work centers were replaced with "university"; thus, avoiding references to paid work and replacing it with academic tasks carried out by students. To check its concordance with the original scale, the new scale was subjected to a reverse translation process (as per Barbero et al., 2008), to check the concordance of the new scale with the original.

After the first Spanish version of the instrument was obtained, the following procedure was followed:

First, specialists in research methodology and instrument construction analyzed the scale to check the extent of the effect that the changes might have had on the internal structure of the scale.

Second, the scale was administered to a group of 10 students who, with their answers and annotations, allowed us to see the extent of the scale's appropriateness in language and representation.

This process of expert validation with the target group allowed the researchers to adjust any confusing terms. The Spanish version of the 22 items that make up the scale (Table A1) was then obtained and digitized using the online platform Microsoft Forms. Subsequently, the form was sent en masse by email to 
participating universities through their respective distribution lists. The 5 Likert-type response options of the original scale had been preserved in the new scale (1- strongly disagree; 2 - disagree; 3- neither disagree nor agree; 4- agree; and 5- strongly agree).

The instructions sent via email described the research objectives, identified the authors, and assured the anonymity of answers provided. No personal data that would allow identification of the students were collected, thus complying with the requirements on the regulation of personal data of the ethics committees of the universities involved as well as the recommendations of the Declaration of Helsinki (2016/679), as approved by the European Parliament of the European Union.

Students were asked for their consent to participate in the study and were informed that their information was to be used solely and exclusively for the study. To accomplish this, a mandatory question was introduced prior to viewing the questionnaire that, if not answered in the affirmative, prevented the completion of the questionnaire.

Data collection began in mid-April (specifically on the 17th), coinciding with the month of confinement of the population in Spain due to the state of alarm decreed by the Government in response to the COVID-19 pandemic, and ended a month later (May 16), when the first deconfinement measures occurred.

During the period of data collection, all official in-person training activities in Spanish educational institutions (i.e., nursery schools, primary, secondary, high school, vocational training centers, and university education) were suspended and had to be carried out remotely or online.

The sample comprised 1,744 students $(46.4 \%$ men and $53.3 \%$ women) who were studying at public (84.5\%) and private $(15.5 \%)$ universities in Spain. Their average age was 24.91 years, without significant differences according to gender. A total of $64.7 \%$ of the participants studied at a university center with an exclusive faceto-face teaching modality, while $35.3 \%$ of the students studied in a university with an online or blended teaching modality.

The average age of university students who carried out their studies online was significantly higher (28.71 years) than students who did so through the blended teaching modality (23.09 years); there was a statistically significant difference ( $t=13.496, p<0.01$ ). With regards to their studies, $25.9 \%$ of the participants were in the first year of undergraduate studies, $22.7 \%$ in the second, $21.2 \%$ in the third, $19.9 \%$ in the fourth, and $2 \%$ in the fifth. Only $6.4 \%$ were studying a master's degree, and $3 \%$ were studying for a doctorate. Also, $48.72 \%$ of the students chose a degree in the field of social and legal sciences, $25.26 \%$ in science, $16.58 \%$ in health sciences, and $6.81 \%$ in arts and humanities.

\section{Measures}

To estimate the phenomenon of technostress among university students, we used the technostress questionnaire (Wang and $\mathrm{Li}$, 2019) that was based on a multidimensional personenvironment model. In our proposed instrument, technostress is conceptualized as the result of maladjustment in three main areas of people's interaction with the environment in which they work: from person to organization (person-organization misfit; P-O), person to technology (person-technology misfit; $\mathrm{P}-\mathrm{T}$ ), and people to each other (person-person technology; P-P).
The maladjustment of $\mathrm{P}-\mathrm{O}$ and $\mathrm{P}-\mathrm{T}$ was also conceptualized from two paths: on one hand, the lack of abilities of the subjects, and on the other, a lack of supplies to adapt to changes.

These dimensions were analyzed with university teachers. It is understood that these teachers are essential to the case at hand (university students), so their participation was considered, conceptualizing it as follows:

P-O encompasses both the maladjustment of the abilities of the subjects in relation to the new demands of their condition as students (abilities-demands misfit, A-D) as well as the lack of support or resources on the part of the institution in the face of the new needs of the students (needs-supplies misfit, N-S).

P-T assumes that the technological skills of students will quickly become obsolete due to the constant evolution in technological and information systems, forcing them to work faster and with greater technological demands (A-D). Likewise, inappropriate use of technology may originate from the use of technological tools that are inadequate for the task, or from a lack of customization of available tools (N-S).

$\mathrm{P}-\mathrm{P}$ is conceptualized as the lack of support on the part of other students when carrying out academic tasks, which can increase the feeling of uselessness of new technologies and increase technostress.

\section{Statistical Analyses}

An exploratory factorial analysis (EFA) following the Kaiser principle was carried out using principal components and varimax rotation. The Bartlett sphericity test statistic allowed us to estimate the adequacy of the factorial solution.

Once the main factors were identified through the EFA, a confirmatory factorial analysis (CFA) was carried out to determine the goodness of fit of the factorial structure. The estimation method used was unweighted least squares (ULS). To evaluate the adjustment value of the model, the following indices were used: goodness of fit index (GFI), adjusted goodness of fit index (AGFI), root mean square residual index (RMR), normed fit index (NFI), and relative fit index (RFI). ULS is used for variables that do not follow a normal distribution and is especially recommended when the variables are of the ordinal type (MorataRamírez et al., 2015). In accordance with authors such as Kline (2016), values show a good model fit if RMR $\leq 0.06$ and GFI, AGFI, NFI, and RFI $>0.90$.

To ascertain the psychometric properties of the questionnaire, a reliability analysis was performed by calculating the Cronbach's alpha and Omega reliability coefficients. All analyses were performed using the IBM SPSS statistical software (version 25), AMOS extension for SPSS, and the free-access computer program “R” version 3.1.2 (R Development Core Team, 2007).

\section{RESULTS}

\section{Exploratory Factor Analysis}

The EFA, using the varimax method and based on an eigenvalue greater than 1 , showed very good statistical results $(\mathrm{KMO}=0.950$, $d f=231, p<0.001)$, with an explained variance percentage of 
TABLE 1 | Exploratory factor analysis based on an eigenvalue greater than 1.

\begin{tabular}{|c|c|c|c|}
\hline & 1 & 2 & 3 \\
\hline ADO1 & 0.777 & & \\
\hline ADO2 & 0.738 & & \\
\hline ADO3 & 0.736 & & \\
\hline ADO4 & 0.707 & & \\
\hline ADO5 & 0.710 & & \\
\hline NSO1 & & 0.736 & \\
\hline $\mathrm{NSO} 2$ & & 0.756 & \\
\hline NSO3 & & 0.772 & \\
\hline NSO4 & & 0.713 & \\
\hline ADT1 & 0.637 & & \\
\hline ADT2 & 0.590 & & \\
\hline ADT3 & 0.769 & & \\
\hline ADT4 & 0.677 & & \\
\hline NST1 & & 0.651 & \\
\hline NST2 & & 0.649 & \\
\hline NST3 & & 0.619 & \\
\hline NST4 & & 0.665 & \\
\hline NST5 & & 0.672 & \\
\hline PPF1 & & & 0.782 \\
\hline PPF2 & & & 0.722 \\
\hline PPF3 & & & 0.660 \\
\hline PPF4 & & & 0.516 \\
\hline$\%$ of variance & 28.94 & 18.27 & 13.25 \\
\hline
\end{tabular}

$60 \%$; the three factors clearly differentiated between the proposed general theoretical areas (see Table 1).

In this way, a first factor was observed, which was called the A-D factor. This includes items that indicate an imbalance between the skills of the subjects and the demands of the situation in which they carry out their work. This imbalance can come mainly from two sources: the demands that come from the organization (i.e., the university) and demands of the use of technology (i.e., those that come from the computer programs used).

The second factor grouped all the needs that users have and the needs that have not been covered, thus generating a feeling of stress. These grouped items indicate that this imbalance can come from the institution itself (i.e., the university), as well as from student needs and proper technological resources.

Finally, the third factor referred to as the human factor, grouped the behaviors and responses of students regarding the use of technology within the university.

In the factorial model obtained, two items with moderate factor weights (NST1 and NST2) were observed in a different factor than what would be expected, depending on the theoretical model proposed.

If the factorial solution is forced into five factors, following the model proposed by Wang and Li (2019), the good statistical results of the three-factor solution are maintained $(\mathrm{KMO}=0.950$; $d f=231 ; p<0.001)$, with a slight increase in the explained variance that stood at $68 \%$, but observing the same saturation problems in items NST1 and NST2.

The identification in both analyses of these two items with moderate weights, in a factor different from what might be
TABLE 2 | Exploratory factor analysis (5-factor solution).

\begin{tabular}{|c|c|c|c|c|c|}
\hline & 1 & 2 & 3 & 4 & 5 \\
\hline ADO1 & 0.747 & & & & \\
\hline ADO2 & 0.707 & & & & \\
\hline ADO3 & 0.793 & & & & \\
\hline ADO4 & 0.759 & & & & \\
\hline ADO5 & 0.707 & & & & \\
\hline NSO1 & & 0.802 & & & \\
\hline $\mathrm{NSO} 2$ & & 0.804 & & & \\
\hline NSO3 & & 0.818 & & & \\
\hline $\mathrm{NSO} 4$ & & 0.643 & & & \\
\hline ADT1 & & & 0.508 & & \\
\hline ADT2 & & & 0.568 & & \\
\hline ADT3 & & & 0.743 & & \\
\hline ADT4 & & & 0.593 & & \\
\hline NST3 & & & & 0.819 & \\
\hline NST4 & & & & 0.734 & \\
\hline NST5 & & & & 0.749 & \\
\hline PPF1 & & & & & 0.895 \\
\hline PPF2 & & & & & 0.838 \\
\hline PPF3 & & & & & 0.773 \\
\hline PPF4 & & & & & 0.628 \\
\hline$\%$ of variance & 24.87 & 16.01 & 13.19 & 10.95 & 5.65 \\
\hline$\%$ of accumulated variance & 24.87 & 40.87 & 54.06 & 65.01 & 70.66 \\
\hline
\end{tabular}

TABLE 3 | Results of the confirmatory factor analysis.

\begin{tabular}{lcc}
\hline & Three-factor solution & Five-factor solution \\
\hline RMR & 0.080 & 0.054 \\
GFI & 0.980 & 0.995 \\
AGFI & 0.980 & 0.994 \\
$\mathrm{NFI}$ & 0.980 & 0.994 \\
$\mathrm{RFI}$ & 0.978 & 0.993 \\
$\chi^{2}$ & 3654.825 & 1282.370 \\
\hline
\end{tabular}

expected based on the proposed theoretical model, advised their elimination; a decision that was supported by theoretical reasons, in addition to the statistical criteria. The wording of these two items broke the general response dynamic: in general, the respondents were asked to position themselves (e.g., "my university does not provide me," "my university does not train me," etc.), but for these two items, they were asked opinions about the role played by the ICT in their university (e.g., "ICT in my university is not effective" and "ICT in my university is not relevant").

After these items were eliminated, another EFA was carried out, obtaining a factorial solution of five factors, with an explained variance percentage of $70 \%(\mathrm{KMO}=0.947, d f=190$, $p<0.001$; see Table 2).

\section{Confirmatory Factor Analysis}

Following the EFA, the two factor models resulting from the elimination of the items NST1 and NST2 were tested using confirmatory factor analysis. 


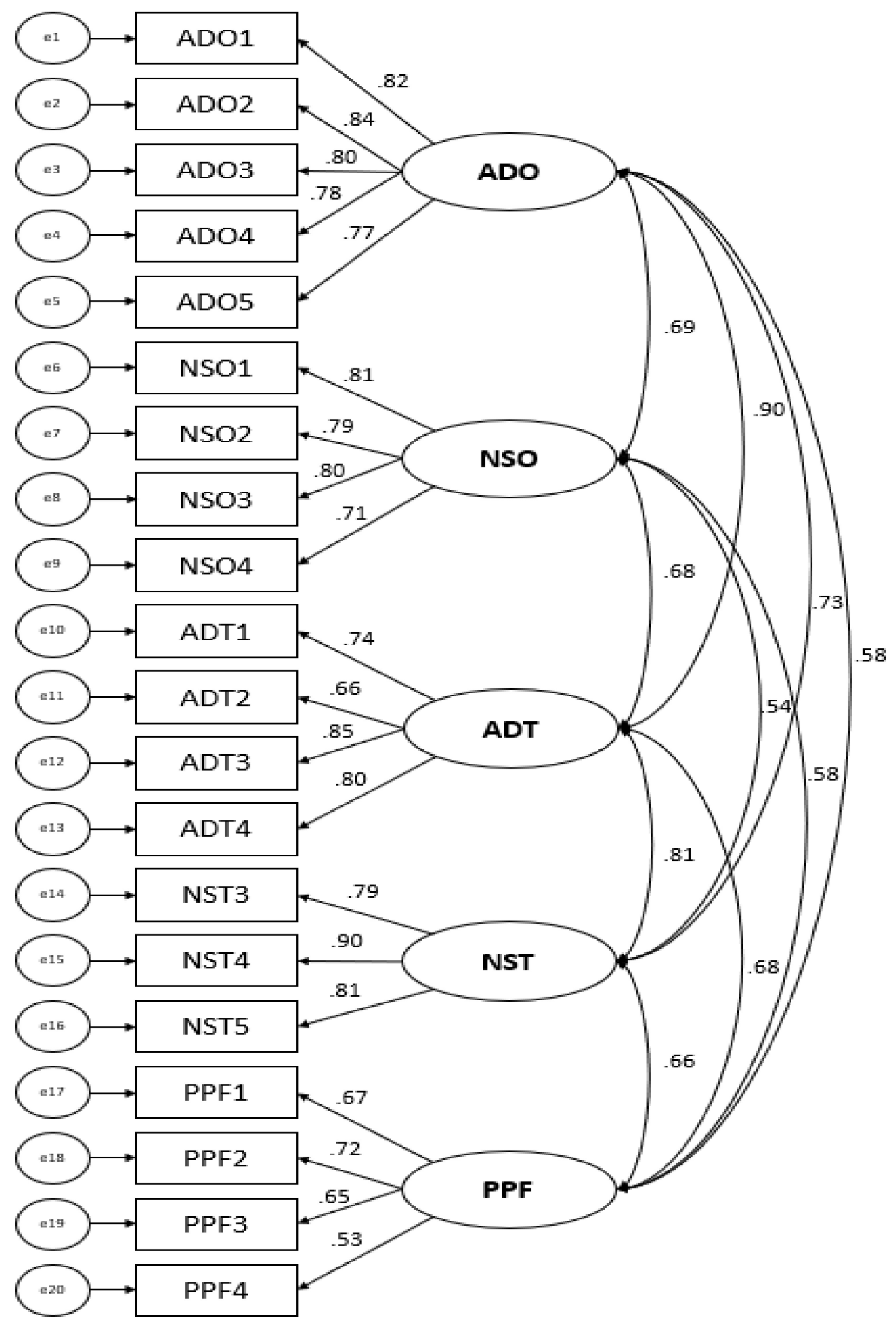

FIGURE 1 | Confirmatory factor analysis. 
The results obtained from the confirmatory factor analysis with the three-factor solution showed an unacceptable RMR index based on the proposed standards $(\mathrm{RMR}=0.07)$, which meant that the theoretical model obtained had to be discarded.

The factorial solution of five factors was the solution that obtained the best statistical results based on the established requirements (RMR $\leq 0.06$ and GFI, AGFI, NFI, and RFI $>0.90$ ), with a goodness of fit that showed the robustness of the model (see Table 3).

As shown in Figure 1, the correlations ranged from 0.90 (organizational and technological abilities-demands) to 0.54 (organizational and technological needs-supplies). The factor weights of the items that made up each of the factors were high (in most cases exceeding 0.70), except when considering the interpersonal interaction factor (person-person), where the factor weight of the last item did not reach the aforementioned cut-off point (see Figure 1).

To corroborate the obtained results, a cross-validation was carried out from a random segmentation of the sample according to gender. A subsample of women was used to verify the results obtained from the EFA, while a subsample of men replicated the theoretical model proposed for the confirmatory factor analysis. The results of the EFA with the subsample of women replicated the factorial structure formed by the five factors obtained in the entire sample, which explained $70.74 \%$ of the variance obtained for women $(\mathrm{KMO}=0.945, d f=190, p<0.001)$. While that carried out with the subsample of men, identified a root mean square residual index that was considered acceptable $(\mathrm{RMR}=0.06)$, with good results in the rest of the goodness-of-fit indices $(\mathrm{GFI}=0.995 ; \mathrm{AGFI}=0.993 ; \mathrm{NFI}=0.993 ; \mathrm{RFI}=0.992)$.

To calculate the unidimensionality of the instrument, the analyses were carried out from the matrix of polychoric correlations, obtaining some results practically identical to those obtained in the confirmatory factor analysis. The correlations ranged from 0.896 (organizational and technological abilitiesdemands) to 0.536 (organizational and technological needssupplies), with intermediate scores in the rest of the factors analyzed $(\mathrm{ADO}-\mathrm{NSO}=0.692 ; \mathrm{NSO}-\mathrm{ADT}=0.682 ; \mathrm{ADT}-$ $\mathrm{NST}=0.810 ;$ NST-PPF $=0.657 ; \mathrm{ADO}-\mathrm{NST}=0.733 ; \mathrm{ADO}-$ $\mathrm{PPF}=0.580 ; \mathrm{NSO}-\mathrm{PPF}=0.581 ; \mathrm{ADT}-\mathrm{PPF}=0.676$ ).

\section{Reliability Analyses}

The reliability analysis for the entire scale showed a Cronbach's $\alpha$ of 0.942 , which was considered excellent (Hinton et al., 2004), and this meant all items contributed significantly to the overall result.

Meanwhile, the reliability analysis for the final proposed reduced twenty-item scale showed a Cronbach's $\alpha$ of 0.939 . Considering the type of teaching modality (face-to-face or online), it was observed that the reliability results improved in the sample of university students who carried out their studies online $(\alpha=0.943)$ compared with students who did so face-toface $(\alpha=0.935)$.

Since the scale items were ordinal, and to obtain a more accurate measurement of the reliability of the instrument, the Omega reliability coefficient was calculated, which confirmed the good results obtained $(\Omega=0.96)$, and far
TABLE 4 | Reliability analysis of the factors and psychometric properties of the technostress questionnaire.

\begin{tabular}{|c|c|c|c|c|c|}
\hline & $\alpha$ & $M-i$ & $S D-i$ & $r^{c_{i}-t}$ & $\alpha-i$ \\
\hline ADO & 0.901 & & & & \\
\hline ADO1 & & 11.74 & 19.497 & 0.784 & 0.872 \\
\hline ADO2 & & 11.83 & 19.591 & 0.793 & 0.871 \\
\hline ADO3 & & 12.11 & 19.501 & 0.764 & 0.877 \\
\hline ADO4 & & 12.28 & 20.202 & 0.720 & 0.886 \\
\hline ADO5 & & 11.40 & 19.476 & 0.710 & 0.889 \\
\hline NSO & 0.859 & & & & \\
\hline NSO1 & & 9.03 & 10.421 & 0.747 & 0.802 \\
\hline NSO2 & & 8.80 & 10.546 & 0.737 & 0.806 \\
\hline NSO3 & & 8.82 & 10.396 & 0.752 & 0.800 \\
\hline NSO4 & & 9.05 & 11.309 & 0.586 & 0.868 \\
\hline ADT & 0.847 & & & & \\
\hline ADT1 & & 8.27 & 11.937 & 0.610 & 0.838 \\
\hline ADT2 & & 9.10 & 12.157 & 0.641 & 0.823 \\
\hline ADT3 & & 8.83 & 10.908 & 0.778 & 0.764 \\
\hline ADT4 & & 8.96 & 11.444 & 0.713 & 0.793 \\
\hline NST & 0.872 & & & & \\
\hline NST3 & & 5.08 & 5.485 & 0.766 & 0.810 \\
\hline NST4 & & 4.97 & 5.460 & 0.780 & 0.797 \\
\hline NST5 & & 5.13 & 5.666 & 0.720 & 0.852 \\
\hline PPF & 0.736 & & & & \\
\hline PPF1 & & 7.78 & 8.050 & 0.613 & 0.630 \\
\hline PPF2 & & 7.42 & 7.844 & 0.587 & 0.641 \\
\hline PPF3 & & 7.58 & 7.927 & 0.539 & 0.669 \\
\hline PPF4 & & 6.95 & 8.800 & 0.388 & 0.756 \\
\hline
\end{tabular}

Item factor-correlation $\left(r_{i}-t\right)$, Cronbach's alpha if item deleted $(\alpha-i)$, mean if item deleted $(M-i)$, standard deviation if item deleted $(S D-i)$.

exceeded the acceptable values established by other authors (Campo-Arias and Oviedo, 2008).

The reliability analysis for the factors that made up the reduced scale also showed good reliability, with high values in all the constructs that needed to be measured (see Table 4).

\section{DISCUSSION}

An adaptation of the Wang and $\mathrm{Li}$ (2019) questionnaire was carried out through its translation into Spanish and the adjustment of the items to the new study population, obtaining a twenty-item scale to measure technostress in Spanish university students.

The results obtained in the validation process showed excellent psychometric results and a factor structure that indicated that technostress can be conceptualized within the theory of personenvironment interaction, as a product of the imbalance between demands (abilities) and resources (needs), in addition to being influenced by the behavior of other students.

The conceptualization of technostress observed by Wang and Li (2019) for Chinese university teachers was maintained in a population as different as the Spanish university students, in that it can be seen that technostress is a multidimensional process where it is observed as well as, for the sample of teachers, 
the interaction mismatches between a person's abilities and the organization's demands in relation to the use of technology (abilities-demands organization, ADO), person's abilities and the demands of the technology itself (abilities-demands technology, ADT), needs of the person and the resources that the organization makes available to them to carry out their tasks (needs-supplies organization, NSO), needs of the person and their own available technological resources (needs-supplies technology, NST), and influence of the interpersonal factor or relations between fellow students regarding the use of technology in their role as students (person-people).

The reliability analysis obtained for the final proposed reduced scale of twenty items maintained the good statistical results of the original scale applied to university teachers and preserved the factor structure obtained in the same population. With the reduction of items that make up the needs-supplies misfit factor (in P-T misfit), the reliability results obtained for this factor increased in relation to the original validation of the instrument.

According to the estimates made by Wang and Li (2019), for the teaching version of the technostress scale, a Western adaptation of the technostress scale for university students would consist of twenty items (with a total possible scores ranging from 20 to 100 ), indicating that the higher the score, the higher the level of technostress. Specifically, a score of 20 would indicate the absence of technostress, a score of 21-60 a mild level of technostress, a score of 61-80 a moderate level of technostress, and a score $>81$ a severe level of technostress.

Moreover, this study addressed the limitations of an initial adaptation and validation of this instrument among Chinese university students (Wang et al., 2020), where the authors pointed out the need for the scale to be validated from the Western cultural context, using a more balanced sample of men and women and a greater representative sample of different universities.

Overcoming the limitations described above, a validation of the technostress questionnaire was carried out for Western university students, starting from the version already validated among university teachers, which allowed for a more complete view compared with the process of validation of the technostress questionnaire among Chinese university students (Wang et al., 2020).

The results obtained in the present study offer a more complete view of the phenomenon of technostress among university students with a 20 -item scale that differentiated skills and resources, both organizational (university) and technological, and also incorporated the interactions that can occur between students when using technology in the educational environment.

\section{REFERENCES}

Alam, M. (2016). Technostress and productivity: Survey evidence from the aviation industry. J. Air Trans. Manag. 50, 62-70. doi: 10.1016/j.jairtraman.2015.10.003 Avanzi, L., Fraccaroli, F., Castelli, L., Marcionetti, J., Crescentini, A., Balducci, C., et al. (2018). How to mobilize social support against workload and burnout: the role of organizational identification. Teach. Teacher Educ. 69, 154-167. doi: $10.1016 /$ j.tate.2017.10.001
Undoubtedly, these data may represent more than one element of the feeling of technostress, which allows for a more complete view than that obtained by the authors (Wang et al., 2020) in the process of developing and validating their technostress scale among university students, which only considered the technological dimension of these factors (ADT, NST), excluding the organizational and interpersonal interaction aspects that can influence the technological stress process.

Despite the results obtained, this study has some limitations that must be considered when assessing the representativeness of the results.

First, a cross-sectional design was adopted to obtain the data, which does not allow for the establishment of causal relationships; thus, it is necessary to carry out longitudinal studies to assess such relationships.

Second, the data were obtained by means of a self-evaluation questionnaire. Hence, it may be interesting to use objective data to contrast the information provided by the subjects themselves.

Third, different variables such as the type of university (public-private) or geographical location could improve the representativeness of the study and the validity of the questionnaire.

Finally, the data collection was carried out during a period of special stress among the participants, such as the compulsory use of new technologies for the continuation of their studies during the period of confinement necessitated by the COVID-19 crisis, the instrument should be tested once this situation has passed to verify the stability of the results.

\section{DATA AVAILABILITY STATEMENT}

The raw data supporting the conclusions of this article will be made available by the authors, without undue reservation, to any qualified researcher.

\section{ETHICS STATEMENT}

Ethical review and approval was not required for the study on human participants in accordance with the local legislation and institutional requirements. The patients/participants provided their written informed consent to participate in this study.

\section{AUTHOR CONTRIBUTIONS}

All authors listed have made a substantial, direct and intellectual contribution to the work, and approved it for publication.

Ayyagari, R., Grover, V., and Purvis, R. (2011). Technostress: Technological antecedents and implications. MIS Q. 35, 831-858. doi: 10.2307/41409963

Barbero, M. I., Vila, E., and Holgado, F. P. (2008). Tests Adaptation in crosscultural comparative studies. Acción Psicol. 5, 7-16. doi: 10.5944/ap.5.2.454

Brod, C. (1984). Technostress: The Human Cost of the Computer Revolution. Boston, MA: Addison-Wesley.

Campo-Arias, A., and Oviedo, H. C. (2008). Propiedades psicométricas de una escala: la consistencia interna. Rev. Salud Públ. 10, 831-839. 
Chandra, S., Shirish, A., and Srivastava, S. (2019). Does technostress inhibit employee innovation? Examining the linear and curvilinear influence of technostress creators. CAIS 44, 299-331. doi: 10.17705/1CAIS. 04419

Chen, L. (2015). Validating the technostress instrument using a sample of Chinese knowledge workers. IIMA 24, 65-82.

Chen, L., and Muthitacharoen, A. (2016). An empirical investigation of the consequences of technostress: Evidence from China. IRMJ 29, 14-36. doi: 10.4018/irmj.2016040102

Demerouti, E., Bakker, A., Nachreiner, F., and Schaufeli, W. (2001). The job demands-resources model of Burnout. J. Appl. Psychol. 86, 499-512. doi: 10. 1037/0021-9010.86.3.499

Edwards, J. (1996). An examination of competing versions of the personenvironment fit approach to stress. AMJ 39, 292-339. doi: 10.2307/256782

Edwards, J., Caplan, R., and Harrison, R. (1998). "Person-environment fit theory: conceptual foundations, empirical evidence, and directions for future research," in Theories of Organizational Stress, ed. C. L. Cooper (Oxford: Oxford University Press), 28-67.

Fischer, T., and Riedl, R. (2017). Technostress research: a nurturing ground for measurement pluralism? CAIS 40, 375-401. doi: 10.17705/1CAIS.04017

Fuglseth, A., and Sørebø, O. (2014). The effects of technostress within the context of employee use of ICT. Comput. Hum. Behav. 40, 161-170. doi: 10.1016/j.chb. 2014.07.040

Galluch, P., Grover, V., and Thatcher, J. (2015). Interrupting the workplace: Examining stressors in an information technology context. JAIS 16, 1-47. doi: 10.17705/1jais.00387

Harrison, R. (1978). "Person-environment fit and job stress," inStress at Work, eds C. Cooper, and R. Paye (New York, NY: Wiley), 175-205.

Hinton, P. R., Brownlow, C., McMurray, I., and Cozens, B. (2004). SPSS Explained. London: Routledge Taylor \& Francis Group.

Hsiao, K. (2017). Compulsive mobile application usage and technostress. The role of personality traits. Online Info. Rev. 41, 272-295. doi: 10.1108/OIR-03-20160091

Hung, W., Chang, L., and Lin, C. (2011). "Managing the risk of overusing mobile phones in the working environment: A study of ubiquitous technostress," in Proceedings of the PACIS 2011 - 15th Pacific Asia Conference on Information Systems: Quality Research in Pacific, (Australia: Queensland University of Technology).

Jena, R. (2015). Technostress in ICT enabled collaborative learning environment: An empirical study among Indian academician. Comput. Hum. Behav. 51, 1116-1123. doi: 10.1016/j.chb.2015.03.020

Jung, I., Kudo, M., and Choi, S. K. (2012). Stress in Japanese learners engaged in online collaborative learning in English. BJET 43, 1016-1029. doi: 10.1111/j. 1467-8535.2011.01271.x

Kline, R. B. (2016). Principles and Practice of structural Equation Modeling. New York, NY: The Guilford Press.

Krishnan, S. (2017). Personality and espoused cultural differences in technostress creators. Comput. Hum. Behav. 66, 154-167. doi: 10.1016/j.chb.2016.09.039

Lazarus, R. (1966). Psychological Stress and the Coping Process. New York, NY: McGraw-Hill.

Lazarus, R., and Folkman, S. (1984). Stress, Appraisal, and Coping. New York, NY: Springer.

López-Araujo, B., and Osca, A. (2008). Un modelo para predecir el tecnoestrés y la satisfacción en teletrabajadores. Rev. Psicol. Soc. Aplicada 18, 63-85.

Marchiori, D. M., Mainardes, E. W., and Rodrigues, R. G. (2019). Do individual characteristics influence the types of technostress reported by workers? Int. J. Hum. Comput. Interact. 35, 218-230. doi: 10.1080/10447318.2018.1449713
Morata-Ramírez, M. A., Holgado-Tello, F. P., Barbero-García, I., and Méndez, G. (2015). Análisis factorial confirmatorio. Recomendaciones sobre mínimos cuadrados no ponderados en función del error tipo I de Ji-cuadrado y RMSEA. Acción Psicol. 12, 91-104.

R Development Core Team (2007). R: A Language and Environment for Statistical Computing. Vienna: R Foundation for Statistical Computing.

Ragu-Nathan, T. S., Tarafdar, M., Ragu-Nathan, B. S., and Tu, Q. (2008). The consequences of technostress for end users in organizations: conceptual development and validation. Inf. Syst. Res. 19, 417-433. doi: 10.1287/isre.1070. 0165

Salanova, M. (2003). Trabajando con tecnologías y afrontando el tecnoestrés: el rol de las creencias de eficacia. Rev. Psicol. Trabajo Organiz. 19, 225-246.

Salanova, M., Llorens, S., and Cifre, E. (2007). NTP 730: Tecnoestrés, Concepto, Medida e Intervención Psicosocial. España: Ministerio de Trabajo y Asuntos Sociales.

Salanova, M., Llorens, S., and Cifre, E. (2013). The dark side of technologies: Technostress among users of information and communication technologies. Int. J. Psychol. 48, 422-436. doi: 10.1080/00207594.2012.680460

Srivastava, S., Chandra, S., and Anuragini, S. (2015). Technostress creators and job outcomes: Theorising the moderating influence of personality traits. Inf. Syst. J. 25, 355-401. doi: 10.1111/isj.12067

Tarafdar, M., Tu, Q., Ragu-Nathan, B., and Ragu-Nathan, T. (2007). The impact of technostress on role stress and productivity. JMIS 24, 301-328. doi: 10.2753/ MIS0742-1222240109

Tarafdar, M., Tu, Q., and Ragu-Nathan, T. (2010). Impact of technostress on enduser satisfaction and performance. JMIS 27, 303-334. doi: 10.2753/MIS07421222270311

Tarafdar, M., Pullins, E., and Ragu-Nathan, T. (2015). Technostress: negative effect on performance and possible mitigations. Inf. Syst. J. 25, 103-132. doi: 10.1111/ isj. 12042

Wang, K., Shu, Q., and Tu, Q. (2008). Technostress under different organizational environments: An empirical investigation. Comput. Hum. Behav. 24, 3002 3013. doi: $10.1016 /$ j.chb.2008.05.007

Wang, X., and Li, B. (2019). Technostress Among University Teachers in Higher Education: A Study Using Multidimensional Person-Environment Misfit Theory. Front. Psychol. 10:1791. doi: 10.3389/fpsyg.2019.01791

Wang, X., Tan, S. C., and Li, L. (2020). Measuring university students' technostress in technology-enhanced learning: Scale development and validation. AJET 36, 96-112. doi: 10.14742/ajet.5329

Weil, M., and Rosen, L. (1997). Technostress: Coping with technology @WORK $@ H O M E @ P L A Y$. New York, NY: Wiley.

Yin, P., Davison, R., Bian, Y., Wu, J., and Liang, L. (2014). The sources and consequences of mobile technostress in the workplace.in Proceedings of the 19th Pacific Asia Conference on Information Systems PACIS, (Australia: Queensland University of Technology).

Conflict of Interest: The authors declare that the research was conducted in the absence of any commercial or financial relationships that could be construed as a potential conflict of interest.

Copyright (c) 2020 Penado Abilleira, Rodicio-García, Ríos-de-Deus and MosqueraGonzález. This is an open-access article distributed under the terms of the Creative Commons Attribution License (CC BY). The use, distribution or reproduction in other forums is permitted, provided the original author(s) and the copyright owner(s) are credited and that the original publication in this journal is cited, in accordance with accepted academic practice. No use, distribution or reproduction is permitted which does not comply with these terms. 


\section{APPENDIX}

TABLE A1 | Original and adapted scale used in the adaptation of the instrument to Spanish students.

\begin{tabular}{ll}
\hline Constructs & $\begin{array}{l}\text { Items of the original version of the instrument (Wang } \\
\text { and Li, 2019) }\end{array}$ \\
\hline IDO & I find it difficult to meet the high demands of school policies \\
& regarding the use of ICTs at work. \\
I find it difficult to effectively implement school policies \\
regarding the use of ICTs at work. \\
My current capability is insufficient to implementing school \\
policies regarding the use of ICTs at work. \\
My current skillset is insufficient for the successful \\
implementation of school policies regarding the use of ICTs \\
at work. \\
I find it hard to adjust my current work pattern so as to \\
comply with school policies regarding the use of ICTs at \\
work. \\
My school does not provide me with sufficient professional \\
training to effectively use ICTs at work. \\
MSO \\
My school does not provide me with sufficient incentives to \\
effectively use ICTs at work. \\
The professional training provided by my school is not very \\
relevant for the effective use of ICTs at work. \\
I do not have a culture in my school that encourages the \\
use of innovative tools such as ICTs at work. \\
I feel pressured to effectively use ICTs at work.
\end{tabular}

I find it difficult to effectively use ICTs due to my limited investment of time and effort.

I find it difficult to cope with the high demands of ICTs with my current capability.

I find it difficult to catch up with the rapid changes of ICTS with my current skillset.

NST The ICTs in my school are not effective in helping me increase my productivity at work.

The ICTs in my school are not very relevant for the improvement of my work.

I am irritated by the vast variety of ICTs that are utilized in my school.

The various ICTs complicate my decision-making process at work.

I am annoyed by the excessive use of ICTs in my school. use of ICTs at work.

My colleagues are not encouraging with regard to the innovative use of ICTs at work.

I do not have a team to collaborate with so as to figure out an effective way to use ICTs at work.

I often feel that I am alone in exploring the innovative use of ICTs at work.

Items used in the Spanish version

1. Me resulta difícil satisfacer las altas demandas de mi universidad, con respecto al uso de las TIC

2. Me resulta difícil implementar con eficacia las indicaciones de mi universidad, sobre el uso de las TIC

3. Mi capacidad actual es insuficiente para implementar las indicaciones de universidad, sobre el uso de las TIC.

4. Mis habilidades actuales son insuficientes para implementar las indicaciones de mi universidad, sobre el uso de las TIC.

5. Me resulta difícil ajustar mi patrón de estudio actual para cumplir con las indicaciones de mi universidad, sobre el uso de las TIC.

6. Mi universidad no me brinda suficiente información para usar las TIC de manera efectiva en mi trabajo como estudiante.

7. Mi universidad no me brinda incentivos suficientes para utilizar las TIC de manera efectiva en mis actividades como estudiante.

8. La información facilitada por mi universidad no es muy útil para el uso efectivo de las TIC.

9. No tengo una cultura en mi universidad que fomente el uso de herramientas innovadoras como las TIC.

10. Me siento presionado para usar las TIC de manera efectiva en mis trabajos universitarios.

11. Me resulta difícil utilizar las TIC de manera efectiva debido al poco tiempo y esfuerzo que le dedico

12. Me resulta difícil hacer frente a las altas demandas de las TIC con mi capacidad actual.

13. Me resulta difícil ponerme al día con los rápidos cambios de las TIC.

14. Las TIC en mi centro educativo no son efectivas para ayudarme a aumentar mi productividad como estudiante.

15. Las TIC en mi universidad no son muy importantes

16. Estoy irritado por la gran variedad de TIC que se utilizan en mi universidad

17. Las diversas TIC complican mi proceso de toma de decisiones

18. Me molesta el uso excesivo de las TIC en mi universidad

19. No tengo el apoyo suficiente de mis compañeros para el uso de las TIC.

20. Mis compañeros no son positivos con respecto al uso innovador de las TIC en mi universidad

21. No tengo un equipo con el que colaborar para encontrar una forma eficaz de usar las TIC en en mi trabajo como estudiante universitario.

22. A menudo siento que estoy solo explorando el uso innovador de las TIC. 